\title{
Penerapan Pembelajaran Eksperimen Berbasis Inkuiri Pada Sub Konsep Pencemaran Air Untuk Meningkatkan Hasil Belajar Siswa Dan Sikap Ilmiah Siswa
}

\author{
Maya Ulfah Sutarba \\ Sekolah Tinggi Keguruan dan Ilmu Pendidikan Al-Amin Indramayu \\ Program Studi Pendidikan Ilmu Pengetahuan Alam \\ Email : immay_bgd@yahoo.co.id
}

\begin{abstract}
Abstrak
Penelitian ini bertujuan untuk meningkatkan hasil belajar dan sikap ilmiah siswa dengan penerapan metode eksperimen berbasis penyelidikan. Penelitian ini diharapkan dapat meningkatkan hasil belajar siswa dan sikap ilmiah siswa, sedangkan guru dan sekolah sebagai pertimbangan untuk metode pembelajaran untuk melaksanakan eksperimen berbasis penyelidikan di kelas. Subyek penelitian yaitu VII B dan VII C di Kabupaten SMP Negeri 2 Patrol Indramayu. Metode yang digunakan dalam penelitian ini adalah jenis percobaan dengan instrumen penelitian tentang tes awal dan tes akhir, dalam bentuk materi objektif. Nilai rata-rata tes awal kelompok eksperimen adalah 57,48 dan rata-rata ujian akhir kelompok eksperimen adalah 76,05. Ini berarti bahwa dengan menggunakan metode pembelajaran berbasis penyelidikan, meningkatkan hasil belajar siswa sebesar 18,58\%. Sementara rata-rata awal kontrol tes kelompok rata-rata 57,43 dan tes akhir adalah 70,55. Ini berarti bahwa dengan menggunakan metode konvensional, hasil belajar siswa hanya naik sebesar 13,13\%. Nilai rata-rata sikap ilmiah kelompok eksperimen awal adalah 44 dan sikap ilmiah rata kelompok eksperimen terakhir adalah 75 . Ini berarti bahwa dengan menggunakan metode pembelajaran berbasis penyelidikan, peningkatan nilai sikap ilmiah sebanyak $31 \%$. Sedangkan kelompok rata-rata awal ilmiah kontrol sikap 43 dan rata-rata sikap ilmiah akhir adalah 71. Ini berarti bahwa dengan menggunakan metode konvensional, hasil belajar siswa hanya meningkat sebesar $28 \%$.
\end{abstract}

Kata kunci: Kirim, hasil belajar, sikap ilmiah.

\begin{abstract}
This study aims to improve learning outcomes and scientific attitude of students with the application of the method of inquiry-based experiments. This study is expected to improve student learning outcomes and scientific attitude of students, while teachers and school as consideration for a learning method to implementing inquiry-based experiments in the classroom. The research subject namely VII B and VII C in SMP Negeri 2 Patrol Indramayu district. The method used in this research is a kind of experiment with the instruments of research about the initial test and final test, in the form of objective matter. The average value of the initial test experimental group was 57.48 and the average final test experimental group was 76.05. This means that by using the method of inquiry-based learning, increase student learning outcomes amounted to $18.58 \%$. While the average initial test control group average of 57.43 and the final test is 70.55 . This means that by using conventional methods, student learning outcomes only gone up by $13.13 \%$. The average value of the initial scientific attitude experimental group was 44 and the average scientific attitudes final experimental group was 75 . This means that by using the method of inquiry-based learning, an increase in the value of the scientific attitude as much as $31 \%$. While the average initial scientific attitude control group of 43 and an average of the final scientific attitude is 71. This means that by using conventional methods, student learning outcomes is only increased by $28 \%$.
\end{abstract}

Keywords: Inquiry, learning outcomes, scientific attitude.

\section{PENDAHULUAN}

Pendidikan adalah suatu usaha atau kegiatan yang dijalanan dengan sengaja, teratur dan berencana dengan maksud mengubah atau mengembangkan prilaku yang diinginkan. Sekolah sebagai lembaga formal merupakan sarana dalam rangka pencapaian tujuan pendidikan. Di dalam 
proses belajar mengajar, guru harus memiliki strategi, agar siswa dapat belajar secara efektif dan efesien, mengena pada tujuan yang diharapkan. Salah satu langkah untuk memiliki strategi itu ialah harus menguasai teknik-teknik penyajian, atau biasanya disebut metode mengajar (Roestiyah, 2001).

Selama ini masih banyak guru yang menganggap kegiatan eksperimen menyita banyak waktu, sehingga jarang dilakukan, selain itu kurangnya kemampuan guru dalam mengaplikasikan konsep-konsep yang sulit, kurang terampil dan kreatif dalam mensiasati keterbatasan alat dan bahan menjadi alasan tidak dilakukannya kegiatan eksperimen sehingga berdampak pada siswa yang merasa sulit dalam memahami dan mempelajari konsep penting dalam biologi karena dipandang abstrak oleh siswa. Umumnya pengalaman menunjukan siswa cenderung untuk enggan mempelajari biologi dengan beberapa alasan, tentu bukan terletak pada pelajaran biologi itu sendiri, melainkan juga pada cara penyajiannya yang terkesan membosankan (Roestiyah, 2001).

Untuk mengatasi itu semua peran guru sangat lah penting artinya dalam pencapaian hasil belajar yang optimal. Guru yang baik bukan cuma sekedar mampu dalam penyampaian informasi pada peserta didik namun juga berperan sebagai pendidik. Guru juga harus menjadi pembimbing, pendorong, dan menuntut siswanya dalam belajar sesuai minat dan bakat, sehingga usaha untuk menghantarkan siswa ke taraf yang dicita-citakan dapat tercapai.

Pada pelaksanaan kegiatan belajar mengajar di sekolah, guru sering kali dihadapkan dengan berbagai macam masalah, untuk itu guru diharapkan dapat menanggulangi setiap masalah yang timbul agar dapat mencapai tujuan dan sasaran pendidikan. Dalam praktek pengajaran di sekolah, permasalahan yang dihadapi antara lain : penggunaan metode yang kurang tepat dan kurang bervariasi.

Berdasarkan hasil laporan studi kasus yang dilakukan penulis disalah satu SMP di Kab. Indramayu dan beberapa hasil penelitian yang dilakukan sebelumnya para guru pada umumnya jarang melakukan praktikum karena banyak aslan umumnya dikemukakan antara lain karena tidak ada srana laboratorium, alat dan bahan yang mahal, tidak cukup waktu dan tidak adanya laboran. Disini peneliti mencoba mengatasi kondisi tersebut dengan menerapkan pembelajaran eksperimen berbasis inkuiri. Dimana metode eksperimen dan inkuiri bukanlah metode yang baru diterapkan. Penerapan metode eksperimen yang dirasa efektif dengan sub konsep pencemaran air, diharapkan dapat membangkitkan minat belajar siswa (Roestiyah, 2001).

Sub konsep yang dipilih oleh peneliti dalam penelitian ini adalah tentang pencemaran air. Penulis menggunakan model eksperimen berbasis inkuiri dalam penelitian ini karena berkembang dan kemajuan ilmu pengetahuan yang pesat. Guru dituntut untuk mengembangkan model pembelajaran dari yang bersifat tradisional menjadi pembelajaran yang bersifat pada siswa. Kemudian belajar tidak hanya dapat diperoleh disekolah tetapi juga lingkungan sekitar sehingga lingkungan sekitar menjadi sumber belajar. Model eksperimen berbasis inkuiri melatih siswa untuk memiliki kesadaran sendiri kebutuhan belajarnya. Serta melatih siswa untuk menanamkan kebiasaan belajar berlangsung seumur hidup dan dapat mampu memberikan tujuan positif terhadap meningkatnya hasil belajar siswa dalam pembelajaran. Model eksperimen berbasis inkuiri diterapkan karena beberapa alasan salah satunya adalah dapat melatih siswa untuk belajar secara mandiri sehingga tidak bergantung pada guru sebagai satusatunya sumber belajar.

Adapun sikap ilmiah yang diharapkan dalam penelitian ini adalah sikap yang muncul setelah siswa melakukan proses ilmiah seperti objektif dan jujur dalam mengumpulkan data yang diperoleh. Hal ini berarti bahwa ilmu biologi tidak hanya terdiri atas kumpulan pengetahuan atau berbagai macam fakta yang dihafal, biologi juga merupakan kegiatan atau proses aktif yang menggunakan pikiran dalam mempelajari gejala-gejala alam yang belum dapat direnungkan. Pembelajaran biologi yang yang terlaksana dengan baik dapat membentuk sikap dan nilai positif dalam diri siswa sebagai bekal untuk mengatasi permasalahan dalam kehidupan sehari-hari. 
Berdasarkan latar belakang masalah di atas, dalam penelitian ini dirumuskan masalah dengan pertanyaan "Bagaimana Penerapan Pembelajaran Eksperimen Berbasis Inkuiri Dalam Meningkatkatkan Hasil Belajar dan Sikap Ilmiah Siswa Pada Sub Konsep Pencemaran Air" Untuk menjawab pertanyaan pokok dirumuskan pertanyaan sebagai berikut.

1. Bagaimana peningkatan hasil belajar siswa sesudah penerapan pembelajaran eksperimen berbasis inkuiri pada sub konsep pencemaran air?

2. Bagaimana peningkatan sikap ilmiah siswa sesudah penerapan pembelajaran eksperimen berbasis inkuiri pada sub konsep pencemaran air?

3. Bagaimana keterlaksanaan pembelajaran eksperimen berbasis inkuiri dalam peningkatan hasil belajar dan sikap ilmiah siswa?

\section{PEMBAHASAN}

\subsection{Pengertian Belajar}

Prestasi belajar tidak dapat dipisahkan dari perbuatan belajar, karena belajar merupakan suatu proses, sedangkan prestasi belajar adalah hasil dari proses pembelajaran tersebut. Bagi seorang siswa belajar merupakan suatu kewajiban. Berhasil atau tidaknya seorang siswa dalam pendidikan tergantung pada proses belajar yang dialami oleh siswa tersebut. Belajar adalah proses yang aktif, proses yang mereaksi terhadap semua yang berada disekitar individu. Artinya proses belajar pada siswa yakni proses perubahan tingkah laku siswa melalui berbagai pengalaman yang diperolehnya. (Sudjana, 2001) Sedangkan menurut logan, dkk (1976) dalam Sia Tjundjing (2001) belajar dapat diartikan sebagai perubahan tingkah laku yang relatif menetap sebagai hasil pengalaman dan latihan. Senada dengan hal tersebut, Winkel (1997) berpendapat bahwa belajar pada manusia dapat dirumuskan sebagai suatu aktivitas mental atau psikis yang berlangsung dalam interaksi aktif dengan lingkungan, yang menghasilkan perubahan-perubahan dalam pengetahuan dan nilai sikap. Perubahan itu bersifat relatif konstan dan berbekas.

\subsection{Model Pembelajaran Eksperimen}

Model eksperimen (percobaan) adalah cara penyajian pelajaran dimana siswa melakukan percobaan dengan mengalami dan membuktikan sendiri sesuatu yang dipelajari. Dalam proses belajar mengajar dengan metode percobaan ini siswa diberi kesempatan untuk mengalami sendiri atau melakukan sendiri, mengikuti suatu proses, mengamati suatu objek, menganalisis, membuktikan dan menarik kesimpulan sendiri mengenai suatu objek, keadaan, atau proses sesuatu. Dengan demikian siswa dituntut untuk mengalami sendiri, mencari kebenaran, atau mencoba mencari suatu hukum atau dalil, dan menarik kesimpulan dalam prose yang dialaminya (Djamarah, 2010).

Eksperimen merupakan pendekatan instruksional yang telah menjadi komponen penting dari upaya reformasi ilmu pendidikan (Asosiasi Amerika untuk Kemajuan Sains), standar Pendidikan Sains Nasional mendefinisikan pertanyaan sebagai Sebuah kegiatan multifaset dimana siswa melakukan pengamatan berupa pertanyaan, penelitian pada buku teks dan bahan referensi lain apa sudah dikenal, merencanakan dan melaksanakan investigasi, penggunaan bukti untuk menjelaskan pertanyaan, menggunakan alat untuk mengumpulkan dan menafsirkan data, pertanyaan, dan predikat. (Hook Van J.Stephen).

Model eksperimen mempunyai beberapa tahapan, namun pada hakekatnya kita mengenal adanya tiga tahapan yaitu: merumuskan masalah, melaksakan percobaan diikuti observasi dan menarik kesimpulan. Menurut Nasution (2000) eksperimen sebagai bentuk mengajar dapat mengikuti prosedur sebagai berikut: merumuskan hipotesis, merumuskan definisi operasional, mengontrol dan memanipulasi variabelvariabel, melakukan operasional, menciptakan model dan menafsirkan data. Setiap eksperimen hendaknya mengandung sesuatu yang baru, sehingga pekerjaan itu merangsang dan bukan hanya mengikuti prosedur secara rutin. 


\subsection{Pengertian Model Pembelajaran Inkuiri}

Inkuiri yang dalam bahasa inggris inquiry, berarti pertanyaan atau pemeriksaan, penyelidikan. Inkuiri sebagai suatu proses umum yang dilakukan manusia untuk mencari atau memahami informasi dengan melakukan observasi atau eksperimen untuk mencari jawaban atau memecahkan masalah dengan menggunakan kemampuan berpikir logis.

Menurut Carin dan Sund dalam Rustaman (2007) Inkuiri adalah mencari kebenaran dan pengetahuan. Pencarian dimulai dari adanya suatu masalah di mana seseorang diharapkan menyelesaikan masalah melalui serangkaian observasi dan cara-cara tertentu (Trianto, 2007) menyatakan bahwa pendekatan inkuiri merupakan rangkaian pembelajaran yang melibatkan secara maksimal seluruh kemampuan siswa untuk mencari dan menyelidiki secara sistematis, kritis, logis, dan analitis sehingga dapat merumuskan sendiri penemuannya dengan penuh percaya diri.

Sasaran utama kegiatan pembelajaran inkuiri adalah (1) keterlibatan siswa secara maksimal dalam proses kegiatan belajar; (2) keterarahan kegiatan secara logis dan sistematis pada tujuan pembelajaran; dan (3) mengembangkan sikap percaya pada siswa tentang apa yang dikemukakan dalam proses inkuiri. Maka jika guru menggunakan pendekatan inkuiri dalam pembelajaran biologi, guru tidak harus mengetahui lebih dulu jawaban dari semua pertanyaan. Hal yang penting adalah guru membimbing siswa untuk dapat menemukan pengertiannya sendiri, dan yang lebih penting, pendekatan ini akan menyediakan kesempatan lebih banyak untuk mendapatkan pengetahuan, keterampilan dan pengalaman yang menyenangkan saat belajar biologi.

Dengan pembelajara inkuiri diharapkan pengetahuan dan keterampilan yang diperoleh siswa bukan hasil mengingat seperangkat fakta-fakta tetapi hasil dari menemukan sendiri. Menurut Dettrick. G.W (Rustaman ddk, 2005) penggunaan pendekatan inkuiri berarti membelajarkan siswa untuk mengendalikan situasi yang dihadapi ketika berhubungan dengan dunia fisik yaitu dengan menggunakan teknik yang di- gunakan para ahli peneliti, merancang eksperimen, menganalisis data, menarik kesimpulan dan sebagainya.

\subsection{Hasil Belajar}

Belajar merupakan aktivitas siswa yang membawa perubahan tingkah laku pada siswa tersebut. Menurut Hamalik (2004) belajar adalah suatu proses perubahan tingkah laku individu melalui interaksi dengan lingkungan. Sedangkan menurut Slameto (2003) belajar adalah suatu proses usaha yang dilakukan seseorang untuk memperoleh suatu perubahan tingkah laku yang baru secara keseluruhan, sebagai hasil pengalamannya sendiri dalam interaksi dengan lingkungan. Dengan demikian, maka jelas tujuan belajar itu pada prinsipnya sama yaitu perubahan tingkah laku, hanya berbeda cara atau cara pencapaiannya.

Tingkah laku manusia terdiri dari sejumlah aspek. Hasil belajar akan tampak pada setiap perubahan aspek-aspek tersebut. Adapun aspek-aspek tersebut adalah: pengetahuan, pemahaman, kebiasaan, keterampilan, apresiasi, emosional, hubungan sosial, jasmani, etika, sikap dan lain-lain. Kalau seseorang telah melakukan perbuatan belajar, maka terjadi perubahan pada salah satu atau beberapa aspek tingkah laku tersebut. Dengan demikian dapat diambil kesimpulan bahwa hasil belajar tidak hanya diukur dari aspek kognitif saja, melainkan juga harus memperhatikan aspek afektif dan psikomotornya.

Hasil proses pembelajaran adalah perubahan perilaku individu. Individu akan memperoleh perilaku baru, menetap, fungsional, positif, disadari dan sebagainya. Perubahan perilaku sebagai hasil pembelajaran ialah perilaku pembelajaran secara keseluruhan yang mencakup aspek kognitif, afektif dan motorik, (Haryati, M 2006).

\subsection{Sikap Ilmiah}

Sikap ilmiah merupakan hasrat ingin tahu, kerendahan hati, jujur, objektif, kemauan untuk mempertimbangkan data baru, pendekatan positif terhadap kegagalan, determinasi, keterbukaan dan ketelitian (Amin 1994). Berdasarkan UNESCO (1995), yang termasuk kedalam sikap ilmiah adalah objektivitas, rasa ingin tahu, kooperatif, 
kreativitas, kejujuran, dan fleksibilitas dalam berpikir. Menurut Depdiknas (2002) belajar sains dapat membantu siswa untuk memahami alam dan gejalanya berkaitan dengan penelitian dan penyelidikan sehingga dapat membutuhkan sikap ilmiah.

\section{HASIL DAN PEMBAHASAN}

3.1 Gambaran kemampuan awal sub konsep pencemaran air siswa kelas VII SMPN

Penelitian ini dilaksanakan pada siswa kelas VII di SMPN Dua Patrol Kab. Indramayu sebanyak 80 siswa yang dibagi menjadi dua kelompok, yaitu 40 siswa kelompok eksperimen (Kelompok yang pembelajarannya menggunakan metode Pembelajaran berbasis inkuiri) dan 40 siswa kelompok kontrol (Kelompok yang pembelajarannya menggunakan metode konvensional).

Sebelum melaksanakan proses pembelajaran, diadakan tes awal terlebih dahulu untuk mengukur kemampuan siswa sebelum diberikan perlakuan pembelajaran kepada kelompok eksperimen (Kelompok yang pembelajarannya menggunakan metode pembelajaran berbasis inkuiri)dan kepada kelompok kontrol (Kelompok yang pembelajarannya menggunakan metode konvensional). Adapun data hasil tes awal yang dilakukan terhadap siswa kelas VIIdi SMPN Dua Patrol Kabupaten Indramayu pada kelompok eksperimen dan kelompok kontrol disajikan pada lampiran tabel 4.1. Deskripsi tes awal kelompok eksperimen dan kelompok kontrol dengan menggunakan program PSSS versi 16,0 adalah sebagai berikut

Tabel 1. Deskripsi hasil belajar tes awal

\begin{tabular}{cccccr}
\hline \multicolumn{6}{c}{ Descriptive Statistics } \\
\hline & N & Min & Max & Mean & Std. Deviasi \\
\hline Eksp. & 40 & 40 & 68 & 57.48 & 7.035 \\
\hline Kontrol & 40 & 40 & 68 & 57.42 & 7.531 \\
\hline Valid N & 40 & & & & \\
\hline
\end{tabular}

Dari data pada tabel 4.1 dapat diketahui bahwa tes awal kelompok eksperimen, nilai terkecil 40, nilai tertinggi 68 , rata-rata nilai 57,48 dan standar deviasi 7,035 dan tes awal untuk kelompok kontrol, nilai terkecil 40 , nilai tertinggi 68 , ratarata nilai 57,42 dan standar deviasi 7,531.
Berdasarkan hasil tes awal bahwa kedua kelompok nilainya masih di bawah KKM yang telah ditentukan yaitu 75 .

Untuk lebih jelasnya perbandingan hasil belajar siswa dari tes awal kelompok eksperimen dan kelompok kontrol dapat dilihat dari gambar 1.

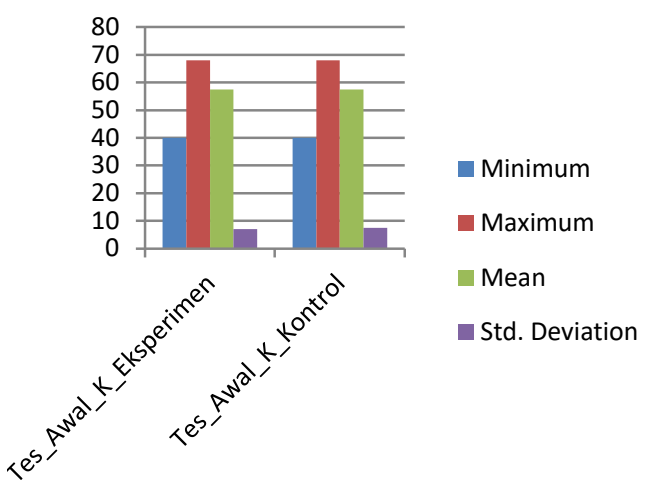

Gambar 1. Grafik perbandingan Rata-rata Hasil Belajar Pretes

3.2 Gambaran Sikap Ilmiah dengan metode pembelajaran berbasis inkuiri

Tabel 2. Deskripsi nilai sikap ilmiah awal Descriptive Statistics

\begin{tabular}{crrrrr}
\hline & N & Min & Max & Mean & Std. Deviasi \\
\hline Eksp. & 40 & 29 & 54 & 43.65 & 7.725 \\
\hline Kontrol & 40 & 29 & 54 & 43.12 & 7.640 \\
\hline Valid N & 40 & & & & \\
\hline
\end{tabular}

Dari data tabel 2 dapat diketahui bahwa nilai sikap ilmiah awal kelompok eksperimen, nilai terendah29, nilai tertingi 54, rata-rata nilai 43.65 dan standar deviasi 7,725 dan nilai sikap ilmiah awal untuk kelompok kontrol, nilai terendah29, nilai tertingi 54, rata-rata nilai 43,12 dan standar deviasi 7,640.

\subsection{Gambaran hasil belajar setelah menggunakan metode pembelajaran berbasis inkuiri}

Setelah dilakukan tes awal kemudian diberikan pembelajaran menggunakan untuk kelompok eksperimen diberikan pembelajaran menggunakan metode Pembelajaran berbasis inkuiri dan untuk kelompok kontrol menggunakan metode konvensional. Setelah pembelajaran selesai diadakan tes akhir. Deskripsi tes akhir kelompok 
kontrol dan kelompok eksperimen dengan menggunakan program SPSS versi 16,0 adalah sebagai berikut :

Tabel 3. Deskripsi hasil belajar

\begin{tabular}{|c|c|c|c|c|c|}
\hline \multicolumn{6}{|c|}{ Descriptive Statistics } \\
\hline & $\mathrm{N}$ & Min & $\operatorname{Max}$ & Mean & Std. Deviasi \\
\hline Eksp. & 40 & 64 & 85 & 76.05 & 5.805 \\
\hline Kontrol & 40 & 55 & 80 & 70.55 & 5.601 \\
\hline Valid N & 40 & & & & \\
\hline
\end{tabular}

Dari data pada tabel 3 dapat diketahui bahwa tes akhir untuk tes akhir kelompok eksperimen, nilai terkecil 64, nilai tertingi 85 , rata-rata nilai 76,05 dan standar deviasi 5,800. Untuk kelompok kontrol, nilai terkecil 55 , nilai tertingi 80 , rata-rata nilai 70,55 dan standar deviasi 5,597. Artinya dengan menggunakan metode Pembelajaran berbasis inkuiri, hasil belajar siswa naik sebesar 18,58\% (dari rata-rata nilai 57,48 menjadi 76,05). Berdasarkan hasil nilai tes akhir kelompok eksperimen diatas nilainya telah memenuhi KKM yang telah ditentukan yaitu 75 .

\subsection{Gambaran Sikap Ilmiah dengan metode Pembelajaran berbasis inkuiri}

Hasil sikap ilmiah tes akhir kelompok eksperimen dan kelompok kontrol siswa dalam proses pembelajaran eksperimen berbasis inkuiri pada sub konsep pencemaran air dengan metode pembelajaran berbasis inkuiri pada Lampiran 2.4.Deskripsi nilai sikap ilmiah akhir kelompok eksperimen dan kelompok kontrol dengan menggunakan program SPSS versi 16,0 adalah sebagai berikut :

Tabel 4 Deskripsi nilai sikap ilmiah

\begin{tabular}{ccrrrr}
\hline \multicolumn{6}{c}{ Tabel 4 Deskripsi nilai sikap ilmiah } \\
\hline \multicolumn{6}{c}{ Descriptive Statistics } \\
\hline Eksp. & 40 & 61 & 86 & 74.68 & 7.667 \\
\hline Kontrol & 40 & 57 & 82 & 71.25 & 7.758 \\
\hline Valid N & 40 & & & & \\
\hline
\end{tabular}

Dari data pada tabel 4 dapat diketahui bahwa nilai sikap ilmiah akhir kelompok eksperimen, nilai terendah 61, nilai tertingi 86, rata-rata nilai 74.68 dan standar deviasi 7,667 dan nilai sikap ilmiah akhir untuk kelompok kontrol, nilai terendah57, nilai tertingi 82 , rata-rata nilai 71,25 dan standar deviasi 7,585.

\subsection{Perbedaan peningkatan hasil belajar siswa}

Untuk mengetahui perbedaan peningkatan pembelajaran sub konsep pencemaran air dengan menggunakan metode konvensional dan metode Pembelajaran berbasis inkuiri di SMPN Dua Patrol Kab. Indramayu. Dari data pada lampiran tabel 2 dapat diketahui bahwa rata-rata tes awal kelompok eksperimen adalah 57,48 dan ratarata tes akhir adalah 76,05 . Artinya dengan menggunakan metode Pembelajaran berbasis inkuiri, hasil belajar siswa naik sebesar $18,58 \%$. Sedangkan rata-rata tes awal kelompok kontrol 57,43 dan rata-rata tes akhir adalah 70,55. Artinya dengan menggunakan metode konvensional, hasil belajar siswa hanya naik sebesar $13,13 \%$. Maka rata-rata hasil belajar kelompok eksperimen lebih besar daripada kelompok kontrol. Artinya dengan menggunakan metode Pembelajaran eksperimen berbasis inkuiri hasil belajar siswa naik sebesar $18,58 \%$.

\subsection{Perbedaan peningkatan sikap ilmiah}

Untuk mengetahui perbedaan peningkatan pembelajaran sub konsep pencemaran air dengan menggunakan metode konvensional dan metode Pembelajaran berbasis inkuiri di SMPN Dua Patrol Kab. Indramayu, terlebih dahulu penulis merekap hasil tes awal dan tes akhir kelompok eksperimen dan kelompok kontrol. Rekapitulasi hasil sikap ilmiah awal dan sikap ilmiah akhir kelompok eksperimen dan kelompok kontrol. Dari data tersebut dapat diketahui bahwa rata-rata nilai sikap ilmiah awal kelompok eksperimen adalah 44 dan rata-rata nilai sikap ilmiah akhir adalah 75 . Artinya dengan menggunakan metode pembelajaran eksperimen berbasis inkuiri, rata-rata nilai sikap ilmiah siswa naik sebesar $31 \%$. Sedangkan rata-rata sikap ilmiah awal kelompok kontrol 43 dan rata-rata nilai sikap ilmiah akhir adalah 71. Artinya dengan menggunakan metode konvensional, sikap ilmiah siswa hanya naik sebesar $28 \%$. Dengan demikian rata-rata nilai sikap ilmiah kelompok eksperimen lebih besar dari pada kelompok kontrol. 


\section{SIMPULAN DAN SARAN}

4.1 Hasil yang diperoleh

1. Berdasarkan hipotesis proses pembelajaran eksperimen berbasis inkuiri dengan metode konvensional, eksperimen berbasis inkuiri lebih baik dalam meningkatkan hasil belajar dan sikap ilmiah siswa dibandingkan dengan metode konvensional.

2. Berdasarkan hasil penelitian dan hasil perhitungan dapat diperoleh nilai ratarata tes awal kelompok eksperimen adalah 57,48 dan rata-rata tes akhir kelompok eksperimen adalah 76,05. Artinya dengan menggunakan metode pembelajaran berbasis inkuiri, terjadi peningkatan hasil belajar siswa sebesar $18,58 \%$. Sedangkan rata-rata tes awal kelompok kontrol 57,43 dan ratarata tes akhir adalah 70,55. Artinya dengan menggunakan metode konvensional, hasil belajar siswa hanya naik sebesar $13,13 \%$. Nilai rata-rata sikap ilmiah awal kelompok eksperimen adalah 44 dan rata-rata sikap ilmiah akhir kelompok eksperimen adalah 75 . Artinya dengan menggunakan metode pembelajaran berbasis inkuiri, terjadi peningkatan nilai sikap ilmiah sebesar $31 \%$. Sedangkan rata-rata sikap ilmiah awal kelompok kontrol 43 dan ratarata sikap ilmiah akhir adalah 71 . Artinya dengan menggunakan metode konvensional, hasil belajar siswa hanya naik sebesar $28 \%$.

\subsection{Saran}

1. Diperlukan penelitian lebih lanjut dengan substrat yang sama namun pada volume yang lebih besar dengan sistem berkenjutan.

2. Diharapkan pengelola sekolah dapat memberikan metode yang bervariasi untuk meningkatkan hasil belajar siswa da sikap ilmiah siswa.

\section{DAFTAR PUSTAKA}

Amin, M. 1994. Mengajarkan Ilmu Pengetahuan Alam Dengan Metode Discovery dan Inkuiri. Jakarta : Departemen Pendidikan dan Kebudayaan.
Depdiknas 2002. Pelatihan Terintegrasi Berbasis Kompetensi Guru Mata Pelajaran Biologi. Jakarta : Depdiknas.

Djamarah, S. B. 2010. Strategi Belajar Mengajar. Jakarta: Rineka Cipta.

Hamalik, O. 2001. Cara Belajar Siswa Aktif. Bandung: Sinar Baru Algensindo.

2004. Proses Belajar Mengajar. Jakarta: Bumi Aksara.

Hook Van J.Stephen 2009. Developing an Understanding of Inquiry by Teachers and Graduate Student Scientists through a Collaborative Professional Development Program. 1 (1): 13-61, ISSN: 1694-609X. On line at. http://www.e-iji.net/dosyalar/iji 2008 $\underline{15 . \mathrm{pdf}}$

Nasution, S. 1995. Didaktif Asas-asas Belajar. Jakarta: Bumi Aksara.

Roestiyah, N.K. 1989. Didatik Metodik. Jakarta: Bumi Aksara.

2001. Strategi Belajar Mengajar. Jakarta: PT Asdi Mahasatya.

Rustaman, N. 2005. Strategi Belajar Mengajar. Malang: Universitas Negeri Malang.

Sudjana, N. 2009. Penilaian Hasil Proses Belajar Mengajar. Bandung: PT Remaja Rosdakarya Offset.

Winkel, W.S. 1997. Psikologi Pendidikan dan Evaluasi Belajar. Jakarta: Gramedia. 